\title{
ZC3H7B wt Allele
}

National Cancer Institute

\section{Source}

National Cancer Institute. ZC3H7B wt Allele. NCI Thesaurus. Code C111981.

Human ZC3H7B wild-type allele is located in the vicinity of 22 q13.2 and is approximately $59 \mathrm{~kb}$ in length. This allele, which encodes zinc finger $\mathrm{CCCH}$ domain-containing protein 7B, is involved in binding to non-structural protein NSP3. A fusion of this gene and the BCOR gene may be associated with low-grade endometrial stromal sarcomas. 